\title{
Diversity and Distribution Pattern of Lichens in the Mid- Elevation Wet Evergreen Forest, Southern Western Ghats, India
}

\author{
Vinayaka, K.S ${ }^{1 *}$, Chetan, H.C ${ }^{2}$, Archana R. Mesta ${ }^{1}$ \\ ${ }^{1}$ Dept of Botany, Kumadvathi First Grade College, Shimoga Road, Shimoga, Karnataka \\ ${ }^{2}$ Azim Premji University, PES Institute of Technology Campus, Pixel Park, B Block, Electronics City, \\ Hosur Road, Karnataka \\ ks.vinayaka@gmail.com, chetan.hcc@gmail.com
}

\begin{abstract}
The objective of this study is to document the lichen species and its host specific plant species in mid-elevational wet evergreen forest. This study was carried out mid elevational forest at different canopy gradient forest types within the ranges from $1100-1300 \mathrm{~m}$, the canopy height varied from 15 to $40 \mathrm{~m}$. The Lichens were enumerated in four different locations at different canopy heights where, temperatures, rainfall and humidity not varied significantly. The sampling was done random quadrats at each site. Total 40 species of lichen belonging to 18 genera and 15 families, of $80 \%$ of species were corticolous, $12.5 \%$ species were saxicolous, $7.5 \%$ species were terricolous. The species $25 \%$ of species were grows more than one type of substrate. The results shown that the higher canopy forest recorded maximum lichen species then lower canopy forest. The higher canopy forest Cullenia exarillata alone recorded $30 \%$ of species, then other species substrates.
\end{abstract}

Keywords: Lichens, Cullenia exarillata, Canopy forest, Western Ghats, Terricolous

\section{INTRODUCTION}

Lichens are the most successful symbiotic organisms having fungal-algal association and form a thallus that does not resemble either symbiotic in the free living (non-lichenized) state [1].The moist forest of the tropics is especially rich in lichens. The tall tree trunks of the forests contain more number of species because of their best sites in the canopy [2]. South Indian lichens were poorly described, as most of the lichenologists selected either Niligiri or Palini hills for their study [3,4]. The Knowledge of lichens from Karnataka part of Western Ghats was attempted by very few workers [2, 5, 6, 7, 8]. Montane range of in Kalakadu Mundanthurai Tiger Reserve (KMTR), which is part of Agasthyamalai Biosphere Reserve, which has go higher endemism as compare to other parts of the Western Ghats. Kalakad Mundanthurai Tiger Reserve (KMTR), which is eastern slope of the Agasthyamalai Biosphere reserve. The study area receives both southwest and northeast monsoons from May to July and October to December respectively [9]. The rainfall patterns does not much changes over seven year from 2000 to 2010 was average is about $3625 \mathrm{~mm}$ and during 2005 the annual rainfall was about $3133 \mathrm{~mm}$. The mean maximum temperatures ranged from $17{ }^{\circ} \mathrm{C}$ to $28{ }^{\circ} \mathrm{C}$ and the minimum temperature from $14{ }^{\circ} \mathrm{C}$ to $19{ }^{\circ} \mathrm{C}$ and annual rainfall ranges from 800 to $4000 \mathrm{~mm}$ $[10,9]$.The primary rain forests are dominated by Cullenia exarillata, Aglaiabourdillonii and Palaquium ellipticum [9]. In this ecosystem information of the lichen flora of KMTR forests is not available. Hence, the purpose of this study is to inventory lichens species distribution within mid elevations ranges from 1000 to $1350 \mathrm{~m}$. Secondary, enumerating the substrate specific lichens species richness and identify the important tree species in the mid-elevation forest.

\section{Materials ANd Methods}

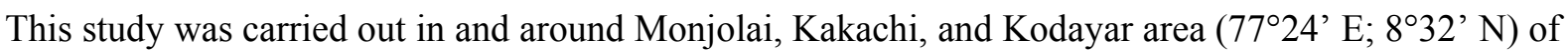
Kalakad Mundanthurai Tiger Reserve (KMTR), altitude range between $1100 \mathrm{~m}$ and $1300 \mathrm{~m}$. The contiguous tracts of mid-elevation moist deciduous to wet evergreen forests, canopy ranges $15-40 \mathrm{~m}$ heights respectively. The dominant species in lower canopy Wendlandia thyrsiflora, Phyllanthus emblica, Gnidia glauca, Glochidion ellipticum and higher canopy are Cullenia exarillata, Aglaiabourdillonii, Palaquium elipticum \& Myristica beddomei $[9,11]$. 
The average annual precipitation recorded at three different sources point at Monjolai, Kakachi and Nalmukku tea estate was between $150 \mathrm{~cm}$ and $340 \mathrm{~cm}$ with minimum of $20 \mathrm{~cm}$ rainfall per month (Fig 1). The mean maximum and minimum temperatures are $24^{\circ} \mathrm{Cand} 16^{\circ} \mathrm{C}$ respectively with two dry seasons between southwest (June-August) and northeast monsoons (October-December). The sampling was preferred only dry seasons during 2007.

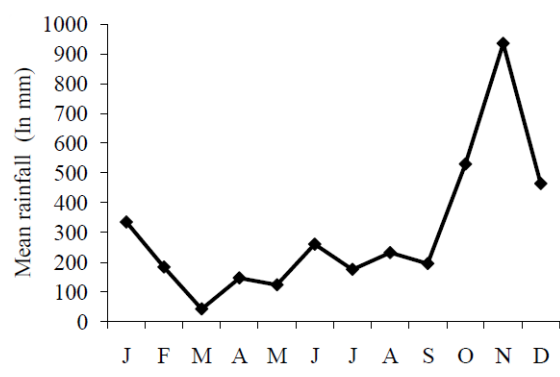

Figure1. The average annual precipitation in KMTR study area

The sampling was had done randomly laid five, $10 \times 10 \mathrm{~m}$ quadrats at each elevation. All four sites were considered different elevation gradients. The average rainfall does not vary much but seasonal variations were found across these elevation. In each transect all substrates were thoroughly searched for the occurrence of lichens. Only representative lichen specimens were collected and packed in brown paper bags, brought in polythene bags to the laboratory [12]. The lichen specimens were dried for 1-2 week to remove all moisture content from the sample, identified on the basis of their morphology, type of fruiting bodies, anatomy and chemistry following recent literature $[13,14,15,4$, 5]. The colour test were performed with the reagent (5\% Potassium hydroxide), C (aqueous solution of Calcium hypochlorite) and PD (Paraphenylene diamine). All lichen specimens were preserved in the herbarium of the Department of Botany, Kumadvathi First Grade College, Shimoga, Karnataka. Diversity indices Shannon and Simpson's Diversity index were calculated according to [16]. The relative frequency, relative density index were calculated by referring [17]

Table1. Habitat details provided at different elevations and its forest canopy

\begin{tabular}{|r|l|l|l|c|l|}
\hline $\begin{array}{c}\text { Study } \\
\text { Sites }\end{array}$ & \multicolumn{1}{|c|}{ Localities } & $\begin{array}{c}\text { Altitude } \\
(\mathbf{m})\end{array}$ & $\begin{array}{c}\text { Forest } \\
\text { canopy }(\mathbf{m})\end{array}$ & $\begin{array}{c}\text { Lichen } \\
\text { species } \\
\text { recorded }\end{array}$ & \multicolumn{1}{|c|}{ Dominated canopy species } \\
\hline 1 & $\begin{array}{l}08^{0} 32^{\prime \prime} \text { to } 8^{0} 31^{\prime \prime}- \\
77^{0} 22^{\prime \prime}\end{array}$ & $\begin{array}{l}1270- \\
1350\end{array}$ & $\sim>30 \mathrm{~m}$ & 20 & $\begin{array}{l}\text { Cullenia exarillata, Aglia, Palaquium } \\
\text { eleipticum, drypetus etc }\end{array}$ \\
\hline 2 & $\begin{array}{l}08^{0} 32^{\prime \prime}-77^{0} 22 \text { to } \\
77^{0} 23^{\prime \prime}\end{array}$ & $\begin{array}{l}1250- \\
1300\end{array}$ & $\sim>30 \mathrm{~m}$ & 15 & $\begin{array}{l}\text { Cullenia exarillata, Aglia, Palaquium } \\
\text { eleipticum, drypetus etc }\end{array}$ \\
\hline 3 & $\begin{array}{l}08^{0} 33^{\prime \prime}-77^{0} 22 \text { to } \\
77^{0} 23^{\prime \prime}\end{array}$ & $\begin{array}{l}1200- \\
1300\end{array}$ & $\sim>20 \mathrm{~m}$ & 15 & Species varied \\
\hline 4 & $\begin{array}{l}08^{\circ} 34^{\prime \prime} \text { to } 8.31 " \\
-7722^{\prime \prime}\end{array}$ & $\begin{array}{l}1100- \\
1250\end{array}$ & $\sim<20 \mathrm{~m}$ & 15 & Species varied \\
\hline
\end{tabular}

\section{RESUlts AND DisCuSSION}

Total 40 lichens species were recorded, which belongs to 18 genera in 15 families (Table 2). The based on the lichen substrata corticolious recored 32 species, followed by five saxicolous and three terricolous (Fig. 2). The foliose were recorded 22 species and followed by 13 fruticose and five crustose species of lichens.

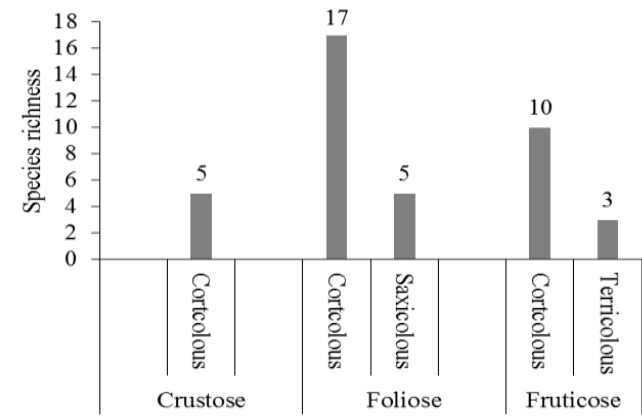

Figure2. Species richness recorded under different types of lichen forms. 
Diversity and Distribution Pattern of Lichens in the Mid-Elevation Wet Evergreen Forest, Southern Western Ghats, India

Table2. Checklist of lichen recorded at different altitudinal gradients with host specific growth.

\begin{tabular}{|c|c|c|c|c|c|c|}
\hline S.No. & Species & Family & Substrate & $\begin{array}{c}\text { Growth } \\
\text { form }\end{array}$ & Host & Status* \\
\hline 1 & Dirineria confluens (Fr.) D.D.Awasthi & Physciaceae & corticolous & foliose & tree & $\mathrm{C}$ \\
\hline 2 & Cladonia fruticulosa Kremp. & Cladoniaceae & terricolous & fruticose & soil & $\mathrm{M}$ \\
\hline 3 & Cladonia cartilaginea Müll. Arg. & Cladoniaceae & terricolous & fruticose & soil & $\mathrm{M}$ \\
\hline 4 & Cladonia ramulosa (With.) J. R. Laundon & Cladoniaceae & terricolous & fruticose & soil & M \\
\hline 5 & $\begin{array}{l}\text { Coccocarpia palmicola (Spreng.) Arv. \& D.J. } \\
\text { Galloway }\end{array}$ & Coccocarpiaceae & saxicolous & foliose & rock & $\mathrm{C}$ \\
\hline 6 & Everniastrum cirrhatum (Fr.) Hale ex Sipman & Parmeliaceae & corticolous & foliose & tree & $\mathrm{M}$ \\
\hline 7 & Graphis arecae Vain. & Graphidaceae & corticolous & crustose & bark & C \\
\hline 8 & Heterodermia comosa (Eschw.) Follmann \& Redón & Physciaceae & corticolous & foliose & tree & $\mathrm{M}$ \\
\hline 9 & Heterodermia diademata (Taylor) D.D. Awasthi & Physciaceae & corticolous & foliose & bark & $\mathrm{C}$ \\
\hline 10 & Heterodermia dissecta (Kurok.) D.D.Awasthi & Physciaceae & saxicolous & foliose & rock & $\mathrm{C}$ \\
\hline 11 & Heterodermia leucomela & Physciaceae & corticolous & foliose & tree & $\mathrm{M}$ \\
\hline 12 & Heterodermia speciosa (Wulfen) Trevis & Physciaceae & corticolous & foliose & tree & $M$ \\
\hline 13 & Laurera keralensis Upreti \& Ajay Singh & Trypetheliaceae & corticolous & crustose & bark & $\mathrm{R}$ \\
\hline 14 & Leptogium chloromelum (Sw.) Nyl. & Collemataceae & corticolous & foliose & tree & M \\
\hline 15 & Leptogium austroamericanum (Malme) C. W. Dodge & Collemataceae & corticolous & foliose & tree & C \\
\hline 16 & Leptogium ulvaceum (Pers.) Vain. & Collemataceae & corticolous & foliose & tree & M \\
\hline 17 & $\begin{array}{l}\text { Nephromopsis isidioidea (Räsänen) Randlane \& } \\
\text { Saag }\end{array}$ & Nephromataceae & corticolous & foliose & branch & $\mathrm{R}$ \\
\hline 18 & Parmelia fuscata P.M. Jørg. & Parmeliaceae & corticolous & foliose & tree & $\mathrm{R}$ \\
\hline 19 & Parmotrema praesorediosum (Nyl.) Hale & Parmeliaceae & saxicolous & foliose & rock & M \\
\hline 20 & Parmotrema reticulatum (Taylor) M. Choisy & Parmeliaceae & corticolous & foliose & tree & C \\
\hline 21 & Parmotrema tinctorum (Despr. Ex Nyl.) Hale & Parmeliaceae & corticolous & foliose & tree & $\mathrm{C}$ \\
\hline 22 & Phyllopsora parvifolia (Pers.) Müll. Arg. & Biotoraceae & corticolous & foliose & tree & M \\
\hline 23 & Porina atriceps (Vain.) Vain. & Trichotheliaceae & corticolous & crustose & tree & $\mathrm{C}$ \\
\hline 24 & Porina decamera Vain. & Trichotheliaceae & corticolous & crustose & tree & $M$ \\
\hline 25 & Parmotrema cristiferum (Taylor) Hale & Parmeliaceae & corticolous & foliose & tree & C \\
\hline 26 & Pseudocyphellaria aurata (Ach.) Vain. & Lobariaceae & corticolous & foliose & branch & $M$ \\
\hline 27 & Pseudocyphellaria intricata (Delise) Vain. & Lobariaceae & saxicolous & foliose & rock & M \\
\hline 28 & Pseudocyphellaria crocata (L.) Vain. & Lobariaceae & corticolous & foliose & tree & M \\
\hline 29 & Ramalina celastri (Spreng.) Krog. Swinscow & Ramalinaceae & corticolous & fruticose & tree & $\mathrm{R}$ \\
\hline 30 & Ramalina hossei Vain. & Ramalinaceae & corticolous & fruticose & twig & M \\
\hline 31 & $\begin{array}{l}\text { Ramalina hossei var. divericata H.Magn. \& G. } \\
\text { Awasthi }\end{array}$ & Ramalinaceae & corticolous & fruticose & twig & $\mathrm{M}$ \\
\hline 32 & Ramalina pacifica Asahina & Ramalinaceae & corticolous & fruticose & tree & $\mathrm{M}$ \\
\hline 33 & Sticta sylvatica (Hunds.)Ach. & Lobariaceae & saxicolous & foliose & rock & M \\
\hline 34 & Thelotrema depressum Mont. & Thelotremataceae & corticolous & crustose & bark & $\mathrm{C}$ \\
\hline 35 & Usnea gabinifera Asahina & Parmeliaceae & corticolous & fruticose & twig & M \\
\hline 36 & Usnea ghattensis G.Awasthi & Parmeliaceae & corticolous & fruticose & tree & $\mathrm{R}$ \\
\hline 37 & Usnea hirta (L.) E.H.Wigg. & Parmeliaceae & corticolous & fruticose & tree & $\mathrm{R}$ \\
\hline 38 & Usnea orientalis Motyka & Parmeliaceae & corticolous & fruticose & twig & $\mathrm{R}$ \\
\hline 39 & Usnea pangiana Stirt. & Parmeliaceae & corticolous & fruticose & twig & $\mathrm{M}$ \\
\hline 40 & Usnea pseudosinensis Asahina & Parmeliaceae & corticolous & fruticose & twig & $\mathrm{R}$ \\
\hline
\end{tabular}

*Status refer only to KMTR (C-Common, R-Rare, M-Moderate)

The members of families Parmeliaceae(12 species) and Physciaceae (6 species) exhibited the maximum diversity. Among the genera Heterodermia (Physciaceae), Parmotrema and Usnea with five species each showed maximum diversity in the area. Leptogium chloromelum and Parmotrema tinctiorumare luxuriantly growing in wet evergreen forests. Coccocarpia, Heterdermia sp.,Parmotrema tinctiorum, P. reticulatum and Ramalina pacifica, Ramalina conduplicans are rich in dry evergreen forests.

In India about 2050 species are reported and it is distributed in eight lichen graphic regions among Western Ghats is the second highest lichen rich area with ca. 1000 species [18, 19]. A study from Karnataka [5] reported 143 species from Sharavithi river basin which represents 34 macrolichens while in the present study KMTR harboured 40 lichen species belonging to 18 genera and 15 families having rich in lichen diversity. More number of lichens was found on tree bark (corticolous 32 species) than any substratum reflecting the importance of the woody component of the forest as a major lichen habitat. The forests of KMTR dominated by Cullenia exarillata, this is one of the species dominate canopy species $[9,10]$. The study from the same habitat shown epiphytic load was higher in 
Cullenia exarillata than other species [20]. The type of vegetation generally supports the growth of macrolichens. Open canopy which is suitable for formation of crustose and foliose lichens such as Dirinaria, Pyxine, Lecanora, Heterodermia, Parmotrema, Usnea, Ramalina and several other species [21, 6]. Macrolichens were documented in similar habitats of costal Brazil [22] and in South Eastern Australia [23].

\section{PLATE - 1}

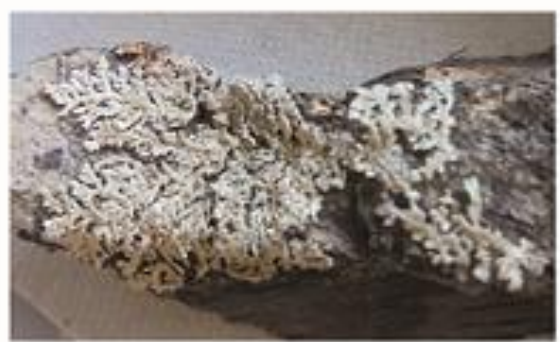

Heterodermia dissecta (Kurok.)

D.D. Awasthi

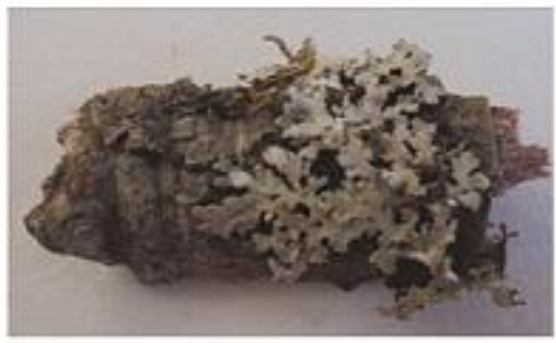

Heterodermia speciosa (Wulf.) Trevis

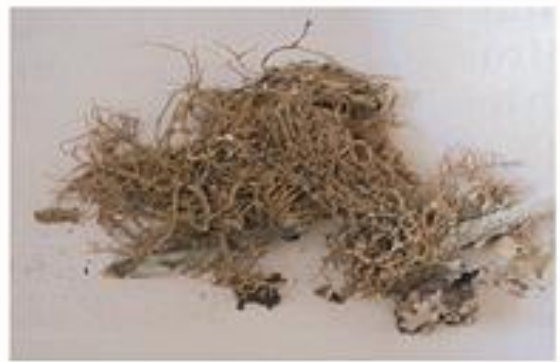

Ramalina hossei vardivericata $\mathrm{H}$. Magn. \& G. Awasthi

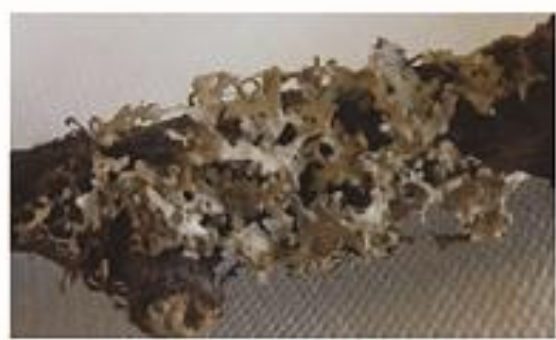

Heterodermia diademata ( Taylor) D. D. Awasthi

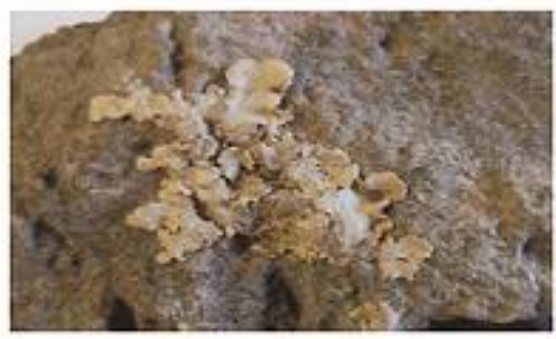

Parmotrema praesorediosum (Nyl.) Hale

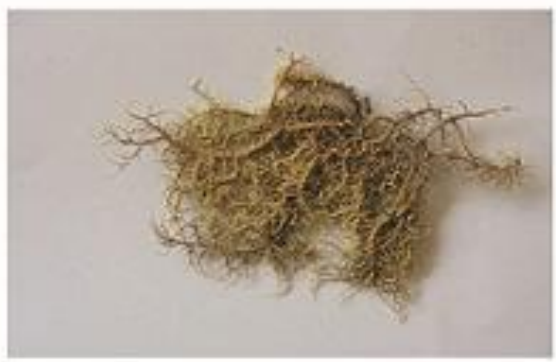

Usnea pseudosinensis Asahina

The distributional pattern of lichens is also depends on micro climatic conditions such as light, water relations and isolation [24, 25]. They [26] found that over 64\% species of lichens occurred on woody component in two clearly landscapes of Chopta-Tungnath and Nanda Devi Biosphere reserve in India. Our study indicated that among the lichen growth forms, foliose lichens showed (58\%) predominance in the area followed by fruticose $(30 \%)$, corticolous lichens represented about $80 \%$ followed by saxicolous $(13 \%)$ and tericolous (7\%) lichen species (Fig 3). Ecological factors play an important role in the growth, development and diversity of lichens species [27, 28]. We observed that the host specificity of macrolichens as they were dominant on the tree branches, bark and were found lower antetity in soil conditions. Most of the lichens prefer tree bark as their substratum, some lichen are more specific to their host $[28,29]$. 


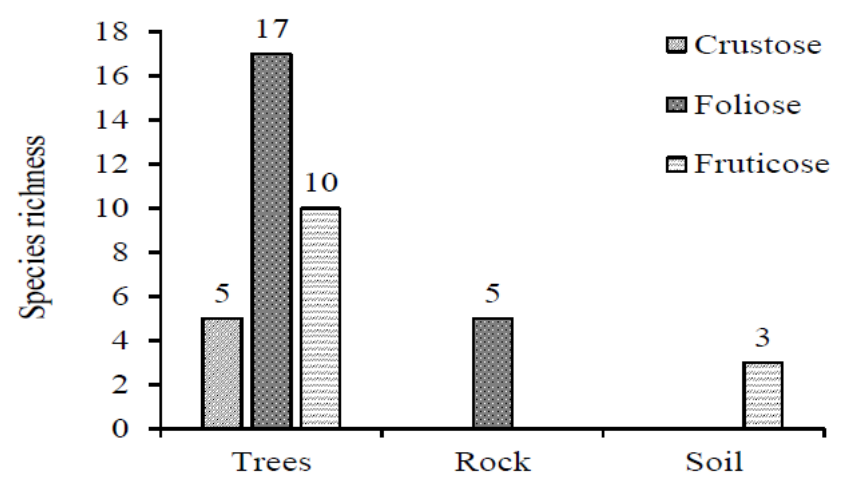

Figure3. Lichen recorded in different substratum respective lichen forms.

Little exploration regarding collection of lichens has been so far carried out in this region, when compare to other parts of India. In this attempt we have enumerate the lichen flora of KMTR and collected 40 species of lichens from 15 families. A majority of the lichen species are found to favour wood. This will be the baseline data for the KMTR. This brings out the importance of woody microhabitats in promoting lichen species diversity. It will very helpful for conservation the lichens diversity in sanctuary and it will helpful for further bio monitoring studies in the area.

\section{ACKNOWLEDGEMENT}

We thank the Rufford Small Grant for financial support to the second author \& DST SERB for financial support to the First author, Tamil Nadu Forest department for giving us the permission to carry out the work and Tamil Nadu Electricity board for their logistics support. We would like to thank to Ganesh T., Soubadra Devy, Nayaka S., Upreti D.K, Krishnamurthy Y.L. and Ganesan R. for all their encouragement during study. We also thankful to Secretary, SVVS, Shikaripura for providing the facility conducting study. We are grateful to all our field colleagues who helped us in the field.

\section{REFERENCES}

[1] Upreti, D.K., Nayaka, S. \& Satya 2005. Enumeration of lichens from Madhya Pradesh and Chhattisgarh, India. J. Appl. Biosci., 31(1): 55-63.

[2] Muktesh Kumar \& Stephen S. 1997. Lichen flora of Western Ghats: An Appraisal, Journal of Economic and Taxonomic Botany, 21(1): 27-39.

[3] Awasthi D.D. 1957. A new species of Parmelia from Kodaikanal, South India. Curr. Sci., 26: 123-124.

[4] Awasthi D.D. 2000. A Compendium of the Macrolichens from India, Nepal and Sri Lanka. Bishen Singh Mahendra Pal Singh Publishers and Distributors of Scientific Books, Dehra Dun, India, 1-580.

[5] Nayaka, S. \& Upreti, D.K. 2002. Lichens flora of Sharavathi River Basin, Shimoga district, Karnataka, India, with six new records. Journal of Economic and Taxonomic Botany, 26(3): 627648.

[6] Balaji, P. \& Hariharan, G.N. 2004. Lichen diversity and its distribution pattren in tropical dry evergreen forests of Gunidy national park (GNP), Chenni. Indian forester, 130(10): 1155-1168.

[7] Vinayaka K.S, Krishnamurthy Y.L and Nayaka S. (2010) Macrolichen flora of Bhadra Wildlife Sanctuary, Karnataka, India. Annuals of Forestry 18 (1): 81-90

[8] Vinayaka K.S., Shravanakumara S., Kumaraswamy Udupa E.S, and Y.L.Krishnamurthy (2011) Diversity of Epiphytic Lichens and Evaluation of Important Host Species Exploited by Them in Tropical Semi-Evergreen and Deciduous Forests of Koppa, Central Western Ghats, India. The Asian and Australasian Journal of Plant Science and Biotechnology 5(1):62-66.

[9] Ganesh, T., R. Ganesan, M. S. Devy, P. Davidar, and K. S. Bawa. 1996. An assessment of plant biodiversity at a mid-elevation evergreen forest of Kalakad Mundanthurai Tiger Reserve, Western Ghats, India. Current Science 71:379-392.

[10] Ganesh, T. and P. Davidar. 1999. Fruit production and frugivore abundance in a wet forest of southern Western Ghats. Journal of Tropical Ecology 15:399-413. 
[11] Patwardhan, P.G. 1983. Rare and endemic lichens of Western Ghats, South western India; in An assessment of threatened plants of India (eds) S.K. Jain \& R.R Rao (Howrah : Botanical survey of India) pp.318-322.

[12] Vinayaka K.S. and Y. L. Krishnamurthy (2012) Enumerations of Macrolichens from Kuvempu University campus, Karnataka, India. Journal of Ecobiology 30(2) 135-142.

[13] Walker, F.J. \& James, P.W. 1980. A revised guide to microchemical techniques for the identification of lichen substances. Bull. Brit. Lichen. Soc., 46: 13-29 (suppl).

[14] Awasthi, D.D. 1988. A key to the macrolichen of India and Nepal. Jour. Hattori Bot. Lab 65: 207-302.

[15] Awasthi D.D. 1999. A Hand Book of Lichens. Bishen Singh Mahendra Pal Singh. Dehra Dun, 1125.

[16] Magurran A.E. 1988. Ecological Diversity and its Measurement. Princeton University Press, New Jersey, pp. 1-179.

[17] Cottam G. and J.T. Curtis. 1956. The use of distance measured in phyto-sociological sampling. J. Ecology, 37: 451-460.

[18] Singh, K.P., Sinha, G.P. \& Bujarbarua, P. 2002. Endemic lichens of India. Geophytology, 33: 116.

[19] Singh, K.P. \& Sinha, G.P. 1997. Lichens. P-195-237, In: Mudugal, V. \& Hajra, P.K. (eds.), Floristic diversity and conservation strategies in India. Vol. I. Cryptogams and gymnosperms. Botanical Survey of India. Kolkata.

[20] Soubadra Devy \& R. Ganesan. 2010. Epiphytic distribution and associated fauna in the Kalakad Mundanthurai Tiger Reserve (http://www.atree.org/epiphytes).

[21] Negi, H.R. and Gadgil, M. 1996. Patterns of distribution of macrolichens in western parts of Nanda Devi Biosphere reserve. Current Science, 71(7): 568-5575.

[22] Macelli, M.P. 1991. Aspects of foliose lichen flora of southeren Central coast of Sau Paulo state, Brazil, Tropical lichens: Their systematics, conservation and Ecology ( D.J Galloway, ed.) Clarendor press, Oxford. pp.151-170.

[23] Pharo, E.J. \& Beattie, A.J. 1997. Bryophytes and Lichen diversity: A compareative study. Aust. J. Ecol., 22: 151-162.

[24] Canters, K.J, Scholler H., Ott S. \& Johns H.M 1991. Microclimatic influences on lichen distribution and community development. Lichenologist, 23(3):237-252.

[25] Wolsely, P.A. Haudson, B.A. 1997.The ecology and distribution of lichens in tropical decidious and evergren forests of northorn Thailand. Journal of Biogeography, 24: 327-343.

[26] Negi, H.R. 2000. On the patterns of abundance and diversity of macrolichens of Chopta-tungnath in the Garhwal Himalaya. Journal of Bioscience, 80: 571-589.

[27] Brunialt, G. \& Giordani, P. 2003. Variability of lichen diversity in a climatically heterogeneous area (Ligaria, NW Italy). Lichenologist, 35: 55-69.

[28] Sequiera S and Muktesh Kumar. 2008. Epiphyte host relationship of macrolichens in the tropical wet evergreen forests of Silent Valleys National Park, Western Ghats, India. Trop. Ecol., 49(2): 211-224

[29] Shravanakumara S., Vinayaka K.S., Kumaraswamy Udupa E.S, Shashirekha B, Praveena V and Y.L. Krishnamurthy (2010) Diversity and Host specificity of Lichens in Koppa Taluk of Central Western Ghats, Karnataka, India. Indian Journal of Forestry 33(3): 437-442. 